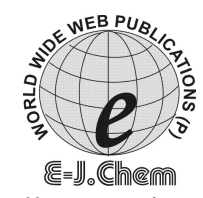

http://www.e-journals.net

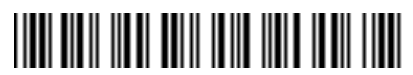

ISSN: 0973-4945; CODEN ECJHAO

E-Journal of Chemistry

Vol. 4, No. 4, pp. 519-522, October 2007

\title{
Palladium Catalyzed Reactions of 2-Nitroaniline with Vinylethers
}

\author{
FARIDEH PIRI*, MINA BEHROUZI FARD MOGHADDAMA and BABAK KARIMI ${ }^{*}$ \\ Department of Chemistry, \\ Faculty of Science, University of Zanjan, Iran. \\ \#Department of Chemistry, \\ Institute for Advanced Studies in Basic Sciences, Zanjan, Iran.
}

farideh_piri@yahoo.com

Received 21 February 2007; Accepted 30 March 2007

\begin{abstract}
A new method for the synthesis of hemiaminal ether have been suggested. The reactions of 2-nitro aniline with vinyl ether in the presence of $\mathrm{PdCl}_{2}\left(\mathrm{CH}_{3} \mathrm{CN}\right)_{2}$ produces hemiaminal ether compounds. The resulting products have been identified by spectral data.
\end{abstract}

Keywords: 2-Nitroaniline, Vinylethers, Paladium catalyst, Hemiaminal ether.

\section{Introduction}

The mechanistic pathway for the condensation of amines with carbonyl compounds involves the formation of a tetrahedral addition intermediate followed by its dehydration to yield imines ${ }^{1}$. These reaction intermediates, formerly referred to as 'carbinolamines', are thermodynamically unstable and are presently termed as 'hemiaminals ${ }^{2-8}$ by IUPAC. The rate of formation of hemiaminals with the variation of substituents and $\mathrm{pH}$ has been the subject of several investigations and many conclusions were established with regard to their mechanisms. Hemiaminal ethers extensively used as protecting group since these can be readily prepared in enantiopure form and the hydroxy and amide functionalities are simultaneously protected by a single protecting group. In the present work, we report a new method for the synthesis of hemiaminal ether from a reaction between 2- nitroanilines with vinyl ethers in the presence of $\mathrm{Pd}(\mathrm{II})$. 1,3-Diethoxybutyl)-(2-nitrophenyl)amine (1), [1ethoxy-3-(1-ethoxyethoxy)-butyl]-(2-nitrophenyl)amine (2), (1, 3- diisobutoxybutyl)-(2nitrophenyl)amine (3) and (3-ethoxy-1-isobutoxybutyl)-(2-nitrophenyl)amine (4) are the first report for new hemiaminal ethers produced from amination of alkenes. 


\section{Experimental}

\section{General procedure}

For the preparation of compounds (1-4), a magnetically stirred mixture of vinyl ether $(0.05 \mathrm{~mol})$ and 2-nitro aniline $(0.01 \mathrm{~mol})$ was added to dichloro bis-acetonitrile palladium(II) $\left[\mathrm{PdCl}_{2}\left(\mathrm{CH}_{3} \mathrm{CN}\right)_{3}\right](0.005 \mathrm{~mol})$ in diethyl ether $(15 \mathrm{~mL})$ and was stirred for $48 \mathrm{~h}$. Then concentration onto silica and flash chromatography (petroleum ether/ diethyl ether 90/10) gave related products (1-4).

\section{Spectral data}

\section{(1, 3-Diethoxybutyl)-(2-nitrophenyl)amine (1)}

${ }^{1} \mathrm{H}$ NMR $\left(500 \mathrm{MHz}, \mathrm{CDCl}_{3}\right) \quad \delta: 1.14(6 \mathrm{H}, \mathrm{m}), 1.26(3 \mathrm{H}, \mathrm{d}, \mathrm{J}=6 \mathrm{~Hz}), 1.87(2 \mathrm{H}, \mathrm{m}), 3.42$ $(2 \mathrm{H}, \mathrm{m}), 3.6(2 \mathrm{H}, \mathrm{m}), 3.84(1 \mathrm{H}, \mathrm{m}), 4.57(1 \mathrm{H}, \mathrm{dd}), 6.50(1 \mathrm{H}, \mathrm{dd}), 6.87(1 \mathrm{H}, \mathrm{d}),$, $(1 \mathrm{H}, \mathrm{dd}), 8.11(1 \mathrm{H}, \mathrm{d}) .{ }^{13} \mathrm{C}$ NMR $\left(125 \mathrm{MHz}, \mathrm{CDCl}_{3}\right) \delta: 15.6,15.7,21.2,41.2,45.3,62.1$, $62.2,100.9,114.5,115.3,127.2,132,136.5,145.1$. MS $\mathrm{m} / z$ (relative intensity) $\left(\mathrm{M}^{+}=282\right.$, $10 \%),(253,3 \%),(236,6 \%),(165,100 \%)$.

\section{[1-Ethoxy-3-(1-ethoxyethoxy)butyl]-(2-nitrophenyl)amine (2)}

${ }^{1} \mathrm{H}$ NMR $\left(500 \mathrm{MHz}, \mathrm{CDCl}_{3}\right)$ d: $\delta 1.24(6 \mathrm{H}, \mathrm{m}), 1.35(6 \mathrm{H}, \mathrm{m}), 2.02(2 \mathrm{H}, \mathrm{m}), 3.51(2 \mathrm{H}, \mathrm{m})$, $3.68(2 \mathrm{H}, \mathrm{m}), 3.93(1 \mathrm{H}, \mathrm{m}), 4.91(2 \mathrm{H}, \mathrm{m}), 6.63(1 \mathrm{H}, \mathrm{dd}), 6.59(1 \mathrm{H}, \mathrm{d}), 7.43(1 \mathrm{H}, \mathrm{dd}), 8.19$ $(1 \mathrm{H}, \mathrm{d}) .{ }^{13} \mathrm{C} \mathrm{NMR}\left(125 \mathrm{MHz}, \mathrm{CDCl}_{3}\right) \delta: 15.6,15.7,21,21.3,42.1,45.3,60.5,62.2,98.4$, 98.9, 114.5, 115.4, 127.5, 132.2, 136.6, 145.1. MS $\mathrm{m} / \mathrm{z}$ (relative intensity) $\left(\mathrm{M}^{+}=326,4 \%\right)$, $(165,89 \%),(73,100 \%)$

\section{(1, 3-Diisobutoxybutyl)-(2-nitrophenyl)amine (3)}

${ }^{1} \mathrm{H}$ NMR $\left(500 \mathrm{MHz}, \mathrm{CDCl}_{3}\right) \delta: 0.9(3 \mathrm{H}, \mathrm{d}), 0.92(3 \mathrm{H}, \mathrm{d}), 0.94(3 \mathrm{H}, \mathrm{d}), 0.95(3 \mathrm{H}, \mathrm{d}), 1.34$ ( $3 \mathrm{H}, \mathrm{d}, \mathrm{J}=6.4 \mathrm{~Hz}), 1.91(2 \mathrm{H}, \mathrm{m}), 1.92(1 \mathrm{H}, \mathrm{m}), 1.98(\mathrm{H}, \mathrm{m}), 3.16(1 \mathrm{H}, \mathrm{dd}), 3.22(1 \mathrm{H}, \mathrm{dd})$, $3.38(1 \mathrm{H}, \mathrm{dd}), 3.41(1 \mathrm{H}, \mathrm{dd}), 3.93(1 \mathrm{H}, \mathrm{m}), 4.61(1 \mathrm{H}, \mathrm{dd}), 6.61(1 \mathrm{H}, \mathrm{dd}), 6.96(1 \mathrm{H}, \mathrm{d}), 7.72$ $(1 \mathrm{H}, \mathrm{dd}), 8.18(1 \mathrm{H}, \mathrm{d}) .{ }^{13} \mathrm{C}$ NMR $\left(125 \mathrm{MHz}, \mathrm{CDCl}_{3}\right) \delta: 19.91(2 \mathrm{C}), 19.94(2 \mathrm{C}), 21.5,29$, 29.1, 41.2, 45.4, 73.3, 73.7, 101.4, 114.6, 115.4, 127.4, 132, 136.6, 145.2. MS $m / z$ (relative intensity) $\left(\mathrm{M}^{+}=338,3 \%\right),(165,100 \%),(138,25 \%),(57,39 \%)$

\section{(3-Ethoxy-1-isobutoxybutyl)-(2-nitrophenyl)amine (4)}

${ }^{1} \mathrm{H}$ NMR $\left(500 \mathrm{MHz}, \mathrm{CDCl}_{3}\right) \delta: 0.91(3 \mathrm{H}, \mathrm{d}), 0.94(3 \mathrm{H}, \mathrm{d}), 1.22(3 \mathrm{H}, \mathrm{m}), 1.35$, (3H, d, J= 6.4 $\mathrm{Hz}), 1.92(2 \mathrm{H}, \mathrm{m}), 1.99(1 \mathrm{H}, \mathrm{m}), 3.25(2 \mathrm{H}, \mathrm{m}), 3.4(2 \mathrm{H}, \mathrm{m}), 3.91(1 \mathrm{H}, \mathrm{m}), 4.62(1 \mathrm{H}, \mathrm{dd})$, $6.61(1 \mathrm{H}, \mathrm{dd}), 6.95(1 \mathrm{H}, \mathrm{t}), 7.42(1 \mathrm{H}, \mathrm{dd}), 8.18(1 \mathrm{H}, \mathrm{d}) .{ }^{13} \mathrm{C} \mathrm{NMR}\left(125 \mathrm{MHz}, \mathrm{CDCl}_{3}\right)$ $\delta$ : 15.71, 19.9 (2C), 21.4, 29.1,41.3, 45.4, 62.2, 73.5, 101.2, 114.5, 115.3, 127.4, 132.1, 136.6, 145.2. MS $\mathrm{m} / \mathrm{z}$ (relative intensity) $\left(\mathrm{M}^{+}=310,9 \%\right),(236,3 \%),(165,100 \%)$, $(138,18 \%),(57,8 \%)$

\section{Results and Discussion}

The reaction of 2-nitro aniline with ethyl vinyl ether in the presence of $\mathrm{PdCl}_{2}\left(\mathrm{CH}_{3} \mathrm{CN}\right)_{2}$ produces (1, 3-Diethoxy-butyl)-(2-nitro-phenyl)-amine (1) with two diasteromer and [1-Ethoxy-3-(1ethoxy-ethoxy)-butyl]-(2-nitro-phenyl)-amine (2) with four diasteromer (Figure 1). 


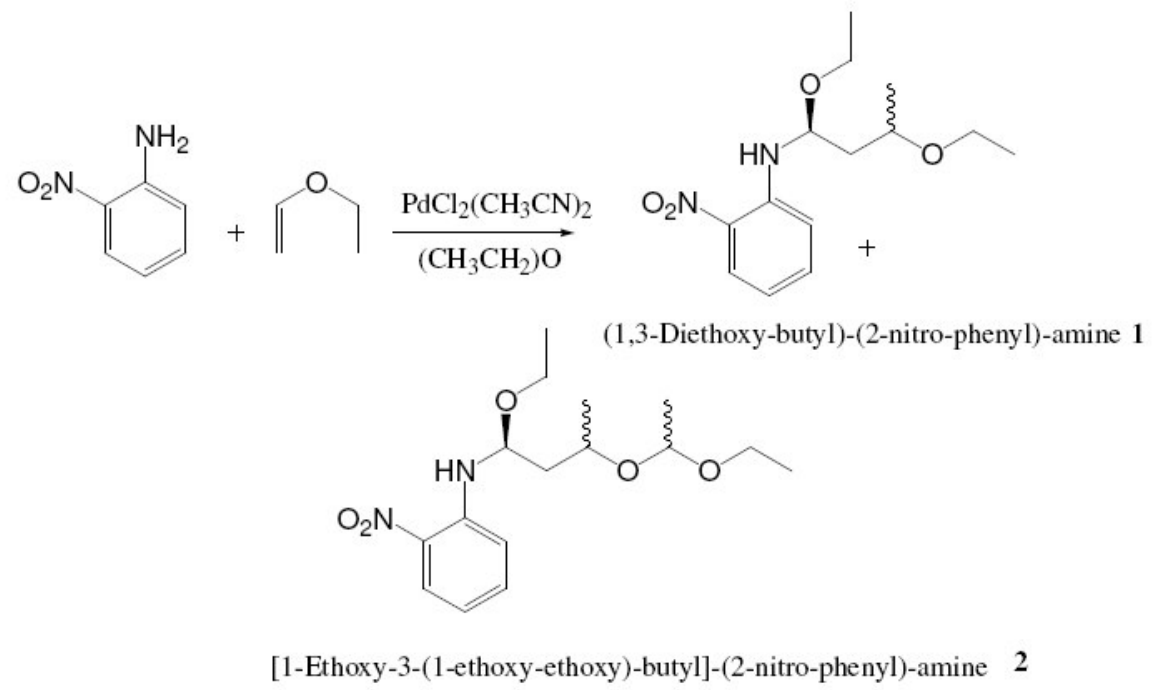

Figure 1. Reaction of 2-nitro aniline with ethyl vinyl ether

Reaction of isobutyl vinyl ether with 2-nitro aniline in the presence of $\mathrm{PdCl}_{2}\left(\mathrm{CH}_{3} \mathrm{CN}\right)_{2}$ and diethyl ether leads to the formation of (1, 3-Diisobutoxybutyl)-(2-nitrophenyl)amine (3) with two configuration of diasteromer and (3-Ethoxy-1-isobutoxybutyl)- (2nitrophenyl)amine (4) with two diasteromer (Figure 2).

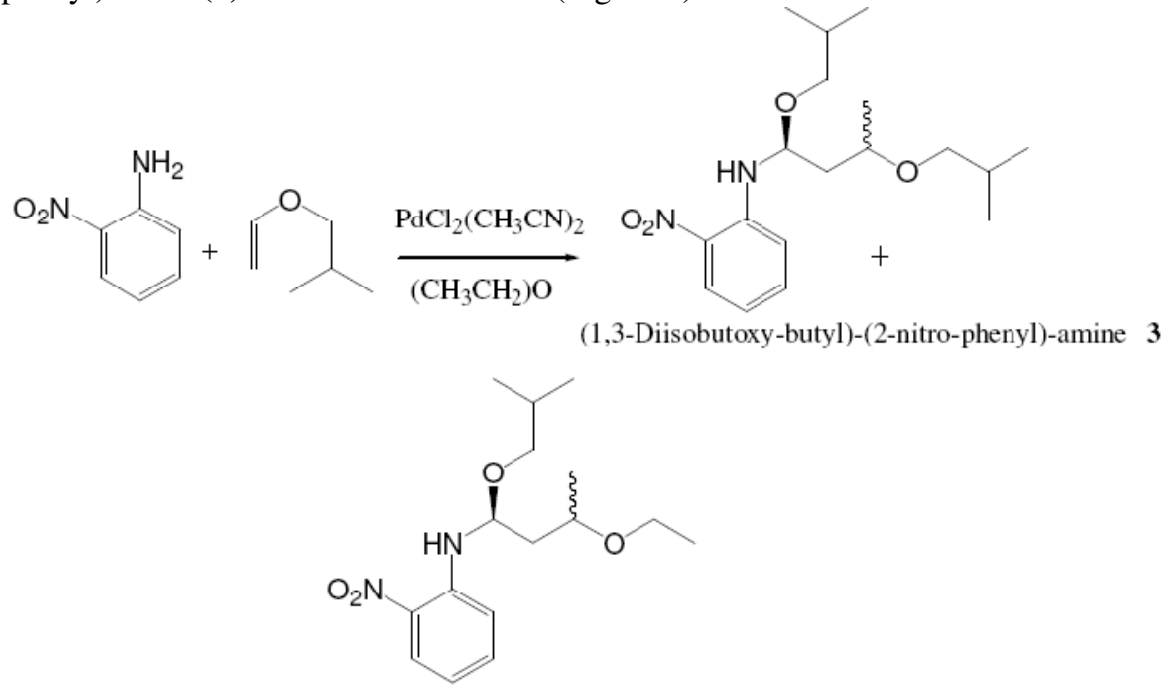

(3-Ethoxy-1-isobutoxy-butyl)-(2-nitro-phenyl)-amine 4

Figure 2. Reaction of 2-nitro aniline with isobutyl vinyl ether.

Analogue products were not obtained from aniline instead of nitro aniline and the same product was not produced in the presence of $\mathrm{Hg}(\mathrm{OAc})_{2}$ instead of $\mathrm{PdCl}_{2}$. Unsubstituted or alkyl substituted aniline are highly reactive with $\mathrm{Pd}^{+2}$ that causes deactivatation of catalysts. Nitro aniline is stabilized by nitro group attached to the ring. In such cases, 
the $\pi$ - complex between palladium ion and vinyl ether are easily established. In the presence of protic acid vinyl ether decomposes to aldehyde. From these results, it can be concluded that above reactions are leads to the formation of (1,3-Diethoxybutyl)-(2nitrophenyl) amine (1) and (1, 3-Diisobutoxybutyl)-(2-nitrophenyl)amine (3) via the following mechanism shown in Figure 3.

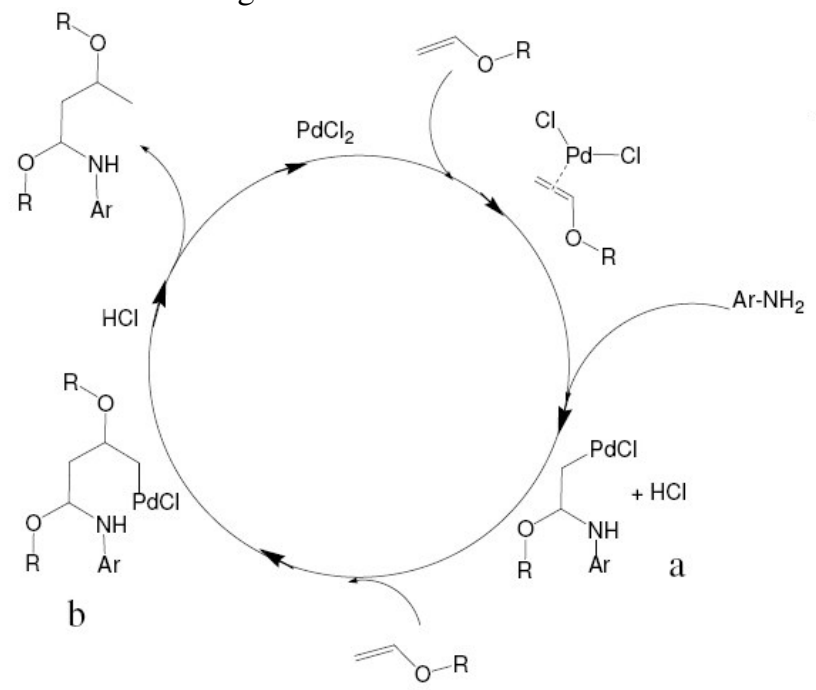

Figure 3. Mechanistic pathway of compounds 1 and 3

Intermolecular aminopalladation of the electron-rich olefinic part of vinyl ether is expected to produce (a). In the same way, addition of vinyl ether generates (b) in the last step which involve exchange of $\mathrm{Pd}(\mathrm{II})$ with $\mathrm{H}^{+}$that affords hemiaminal ether. The structure of the compounds are established by (1-4 the $\left.{ }^{1} \mathrm{H}-\mathrm{NMR},{ }^{13} \mathrm{C}-\mathrm{NMR}\right)$, and mass spectra. For (1, 3-diisobutoxybutyl)-(2-nitrophenyl)amine (3), the assignment of carbon peaks to the respective protons is carried out with the help of ${ }^{13} \mathrm{C}-{ }^{1} \mathrm{H}$ correlation data available from the Hetcor spectrum.

\section{References}

1 Lowry T H and Richardson K S, Mechanism and Theory in Organic Chemistry, $3^{\text {rd }}$ Ed., Harper Collins, New York, 1987.

2 Brewster A G, Broady S, Glenna E, Hermitage S A, Hughesa M, Moloney M G and Woods G, Letters in Organic Chemistry, 2005, 2, 21.

3 Bailey J H, Byfield A T J, Davis P J, Foster A C, Leech M, Moloney M G, Müller M and Prout C K, J Chem Soc, Perkin Trans. 2000, 1, 1977.

4 Garcia-Alles L F, Siebold C, Philipp Schneider, Baumann U and Erni B, Biochemistry, 2004, 43, 13037.

5 Berdini V, Tetrahedron, 2002, 58, 5669.

6 Dixon M J, Andersen O A, Van Aalten D M F and Eggleston I M, Eur. J. Org. Chem, 2006, 5002.

7 Boger D L, Chem. Rev, 2002, 102, 2477.

8 Zajac M A and Vedejs E, Org. Lett, 2004, 6 (2), 237. 


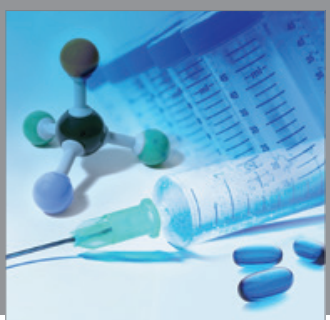

International Journal of

Medicinal Chemistry

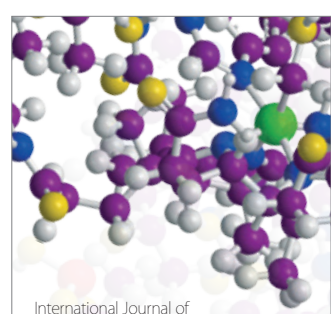

Carbohydrate Chemistry

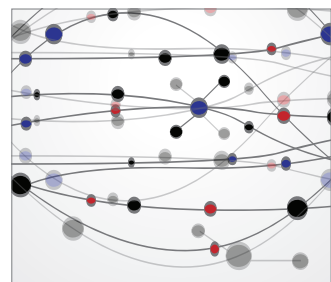

The Scientific World Journal
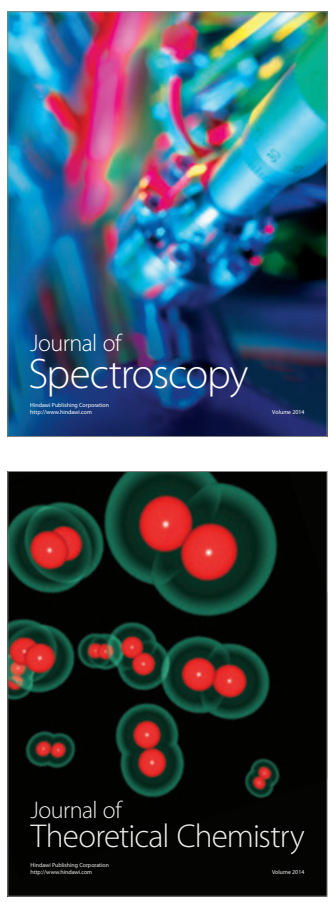
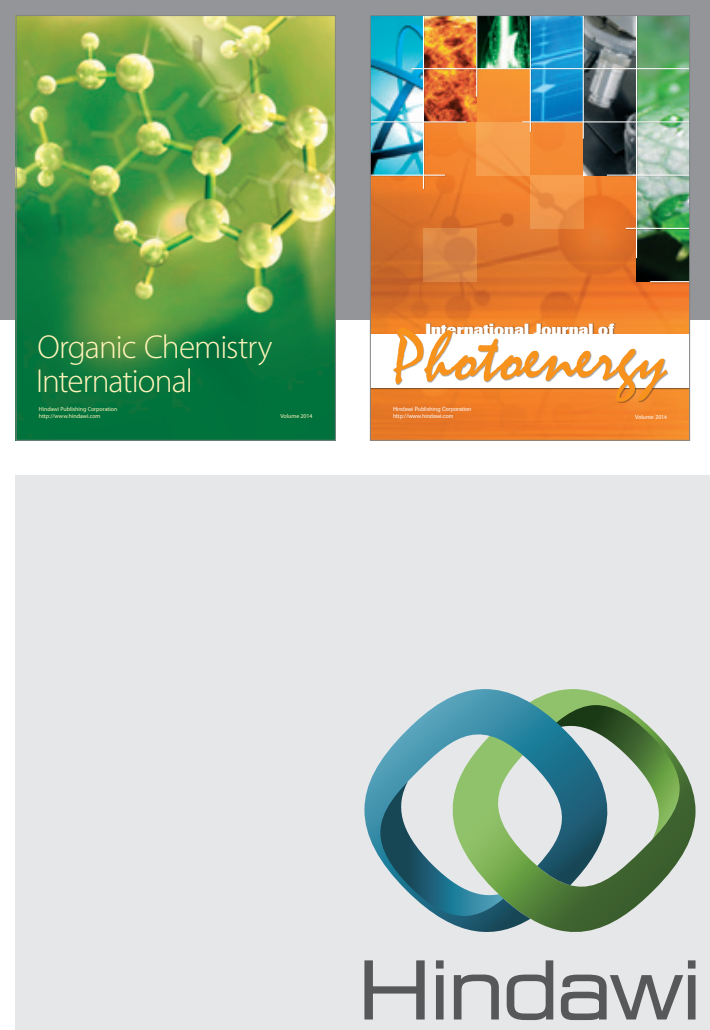

Submit your manuscripts at

http://www.hindawi.com
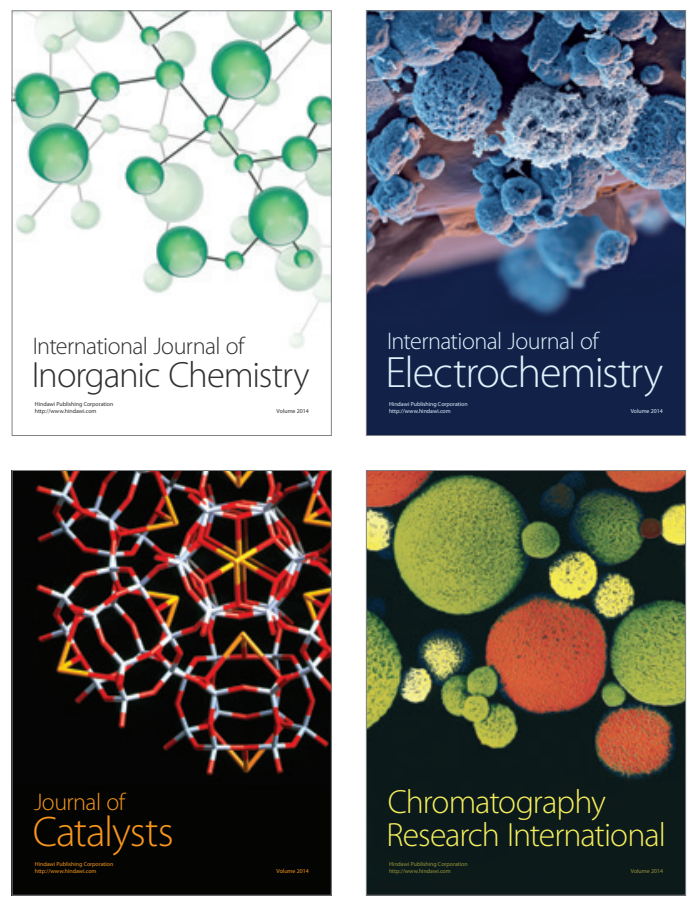
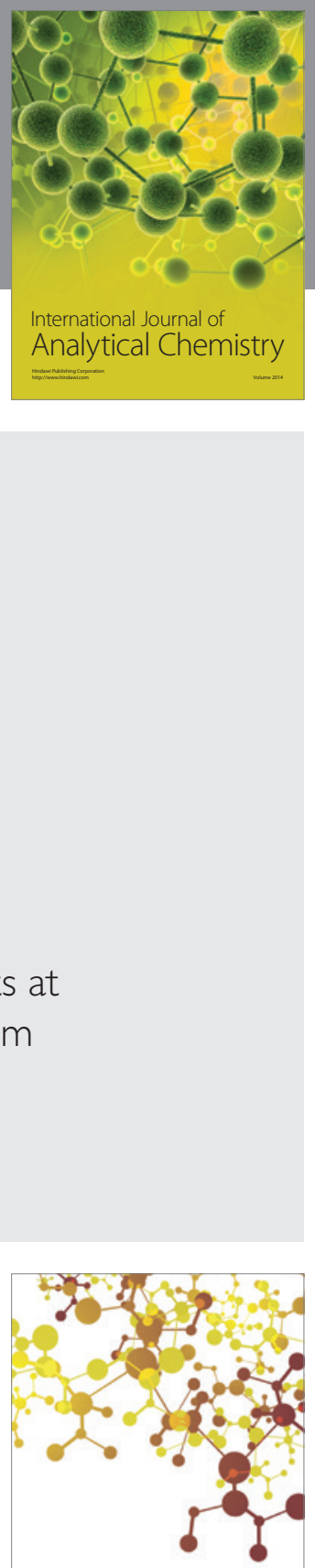

Journal of

Applied Chemistry
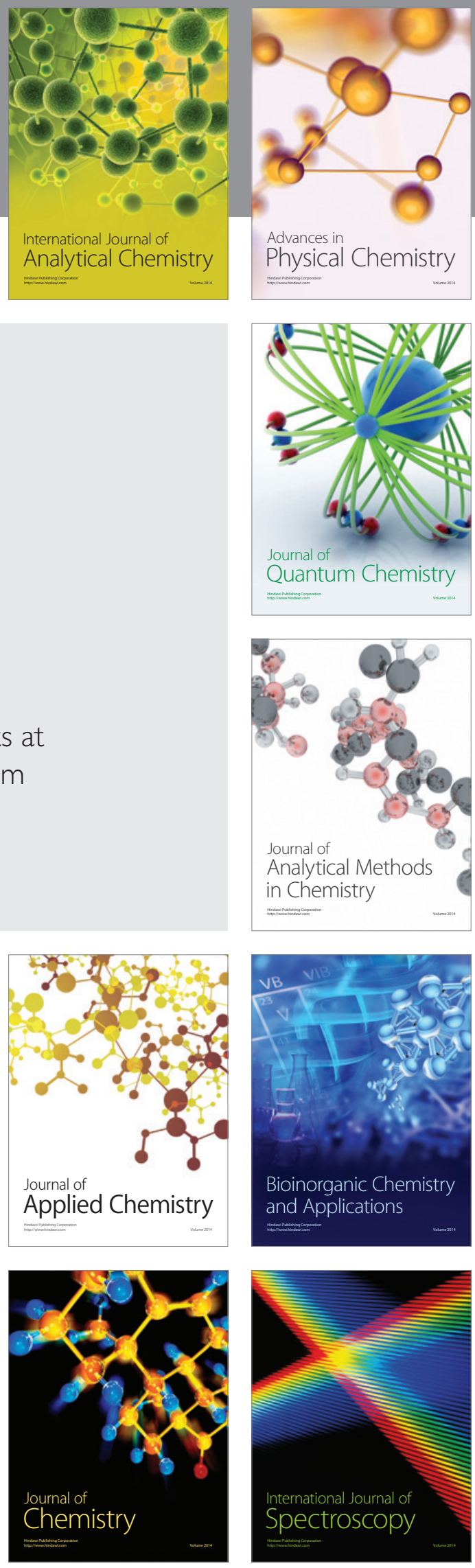